\title{
Wound healing activity of the human antimicrobial peptide LL37
}

\author{
Reinaldo Ramos ${ }^{a}$, João Pedro Silva ${ }^{\mathrm{a}}$, Ana Cristina Rodrigues ${ }^{\mathrm{a}}$, Raquel Costa ${ }^{\mathrm{b}}$, Luísa Guardão ${ }^{\mathrm{b}}$, \\ Fernando Schmitt ${ }^{\mathrm{b}}$, Raquel Soares ${ }^{\mathrm{b}}$, Manuel Vilanova ${ }^{\mathrm{c}, \mathrm{d}}$, Lucília Domingues ${ }^{\mathrm{a}}$, Miguel Gama ${ }^{\mathrm{a}, *}$ \\ a IBB, Institute of Biotechnology and Bioengineering, Centre of Biological Engineering, University of Minho, Campus de Gualtar, 4710-057 Braga, Portugal \\ ${ }^{\mathrm{b}}$ Department of Biochemistry (U38-FCT), Faculty of Medicine, University of Porto, 4200-319 Porto, Portugal \\ ' ICBAS - Instituto de CiênciasBiomédicas de Abel Salazar, Largo do Professor Abel Salazar 2, 4099-003 Porto, Portugal \\ d IBMC - Instituto de Biologia Molecular e Celular, Rua do Campo Alegre 823, 4150-180 Porto, Portugal
}

\section{A R T I C L E I N F O}

\section{Article history:}

Received 24 May 2011

Received in revised form 1 June 2011

Accepted 3 June 2011

Available online 13 June 2011

\section{Keywords:}

Antimicrobial peptide

LL37

Angiogenesis

Wound healing

\begin{abstract}
A B S T R A C T
Antimicrobial peptides (AMPs) are part of the innate immune system and are generally defined as cationic, amphipathic peptides, with less than 50 amino acids, including multiple arginine and lysine residues. The human cathelicidin antimicrobial peptide LL37 can be found at different concentrations in many different cells, tissues and body fluids and has a broad spectrum of antimicrobial and immunomodulatory activities. The healing of wound is a complex process that involves different steps: hemostasis, inflammation, remodeling/granulation tissue formation and re-epithelialization. Inflammation and angiogenesis are two fundamental physiological conditions implicated in this process. We have recently developed a new method for the expression and purification of recombinant LL37. In this work, we show that the recombinant peptide P-LL37 with a N-terminus proline preserves its immunophysiological properties in vitro and in vivo. P-LL37 neutralized the activation of macrophages by lipopolysaccharide (LPS). Besides, the peptide induced proliferation, migration and tubule-like structures formation by endothelial cells. Wound healing experiments were performed in dexamethasone-treated mice to study the effect of LL37 on angiogenesis and wound regeneration. The topical application of synthetic and recombinant LL37 increased vascularization and re-epithelialization. Taken together, these results clearly demonstrate that LL37 may have a key role in wound regeneration through vascularization.
\end{abstract}

(C) 2011 Elsevier Inc. All rights reserved.

\section{Introduction}

Cationic antimicrobial peptides (AMPs) represent the first line of defense against many invading pathogens. These small amphipathic peptides are part of the innate immune system and have a broad-spectrum activity against bacteria, fungi [1] and viruses [17].

However, direct antimicrobial action is not the only, and probably not even the most important task of mammalian AMPs. In fact, these peptides present low antimicrobial activities under serum and tissue conditions [16,17]. Nevertheless, they have affinity for lipopolysaccharide (LPS) and can prevent from lethal endotoxemia by suppressing cytokine production [15]. Moreover, these AMPs appear to be involved in the orchestration of many aspects of innate immunity and the inflammatory response [17].

In mammals, at least two distinct groups of AMPs are found. Defensins are the more representatives and cathelicidins form the second group of mammalian AMPs. Cathelicidins share a highly conserved $\mathrm{N}$-terminal cathelin domain, flanked by a rather variable

\footnotetext{
* Corresponding author. Tel.: +351253 604418; fax: +351253604 429 .

E-mail address: fmgama@deb.uminho.pt (M. Gama).
}

antimicrobial peptide on the C-terminus [32]. The hCAP-18/LL37 is the only known human cathelicidin. Upon stimulation, hCAP-18 is cleaved extracellularly by proteinase 3 to generate the peptide LL37 [36]. The antimicrobial peptide is referred to as LL37, since it has a 37 amino acids sequence starting with two leucines. It is a $4.5 \mathrm{kDa}$, cationic (+6), amphipathic $\alpha$-helical peptide, with a broad spectrum of antimicrobial activity. LL37 and its precursor hCAP18, were first described in leucocytes and testis, but were soon found in a large variety of cells, tissues and body fluids, as summarized by Durr et al. [11]. Upon injury or infection, there is a strong upregulation of hCAP18/LL37, indicating that LL37 assists the immune system. The downregulation of LL37 has been associated with several diseases: a deficiency of LL37 in the skin of patients with atopic dermatitis [29] or chronic ulcers [18] may account for the increased risk for skin infections. Nizet et al. [28] showed that mice with disrupted Cnlp, the gene coding for cathelin-related antimicrobial peptide (CRAMP), showed increased susceptibility to skin infections.

Besides its antimicrobial properties LL37 plays a central role in innate immune responses and inflammation. It has been identified as a potent chemoattractant for mast cells [27], monocytes, $\mathrm{T}$ lymphocytes and neutrophils [42] through formyl peptide receptor-like 1 (FPRL1). The fact that LL37 can attract leukocytes contributes to host defense against infections. LL37 also promotes 
wound healing [18], angiogenesis and arteriogenesis [20] and acts as immune adjuvant [21].

Acute wounds normally heal in a very orderly and efficient manner characterized by four distinct, but overlapping phases: hemostasis, inflammation, proliferation and remodeling. All these phases are strictly connected and play a key role for a complete and proper restoration of the injured tissue [10]. The inflammatory phase is initiated immediately upon injury. Several inflammatory cells migrate to the wound site to fight infection and remove debris. The proliferative phase is characterized by the formation of granulation tissue, epithelialization, and angiogenesis. Then, the new collagen matrix becomes cross-linked and organized during the final remodeling phase. Numerous cell-signaling events are required to generate this efficient and highly controlled repair process.

In this work, we demonstrate that P-LL37 produced by recombinant techniques in our laboratory [33] preserves its immunophysiological properties and promotes wound healing through re-epithelialization and vascularization in dexamethasone-treated mice.

\section{Materials and methods}

\subsection{Animals}

Animal experiments were conducted according to accepted standards of humane animal care (Declaration of Helsinki, European Community guidelines (86/609/EEC) and Portuguese Act (129/92) for the use of experimental animals).

\subsection{Reagents}

All chemicals, media and reagents were purchased from Sigma-Aldrich except stated otherwise. Synthetic LL37 (LLGDFFRKSKEKIGKEFKRIVQRIKDFLRNLVPRTES) was purchased from Bachem, Switzerland. Recombinant P-LL37 (PLLGDFFRKSKEKIGKEFKRIVQRIKDFLRNLVPRTES) was expressed and purified as described previously [33]. Briefly, the DNA encoding the fusion protein LK-CBM3-LL37 was successfully cloned in pET21a and expressed in Escherichia coli BL21 DE3 (Novagen) in Luria-Broth (LB) medium. The fusion protein was purified on cellulose CF11 and formic acid was applied to cleave LL37 from the fusion carrier (LK-CBM3). The resulting recombinant P-LL37 was finally purified by reverse-phase HPLC.

\subsection{Culture of murine bone marrow-derived macrophages (BMDM); suppression of TNF production by LPS-activated macrophages}

Macrophages were obtained from mouse bone marrow as follows: mice were sacrificed and femurs and tibias removed under aseptic conditions. Bones were flushed with Hanks' balanced salt solution. The resulting cell suspension was centrifuged at $500 \times \mathrm{g}$ and resuspended in RPMI 1640 medium supplemented with $10 \mathrm{mM}$ HEPES, 10\% heat-inactivated fetal bovine serum (FBS), $60 \mu \mathrm{g} / \mathrm{ml}$ penicillin/streptavidin, $0.005 \mathrm{mM} \beta$-mercaptoethanol (complete RPMI [CRPMI]), and 10\% L929 cell conditioned medium. To remove fibroblasts or differentiated macrophages, cells were cultured on cell culture dishes (Sarstedt, Canada), overnight at $37^{\circ} \mathrm{C}$ in a $5 \% \mathrm{CO}_{2}$ atmosphere. Then, nonadherent cells were collected with warm cRPMI, centrifuged at $500 \times \mathrm{g}$, distributed in 96 -well plates (Sarstedt, Canada) at a density of $1 \times 10^{5}$ cells/well, and incubated at $37^{\circ} \mathrm{C}$ in a $5 \% \mathrm{CO}_{2}$ atmosphere. Four days after seeding, $10 \%$ of L929 cell conditioned medium was added, and the medium was renewed on the seventh day. After 10 days in culture, cells were completely differentiated into macrophages. This method allows for the differentiation of a homogenous primary culture of macrophages that retain the morphological, physiological and surface markers characteristics of these phagocytic cells $[26,39,43]$. LPS was then incubated with the macrophages culture. At the same time, synthetic LL37 and P-LL37 were added at different concentrations. After $24 \mathrm{~h}$, the supernatants were removed and tested for TNF- $\alpha$ production by ELISA (eBioscience).

\subsection{Cell culture experiments}

Human microvascular endothelial cells (HMECs) and human umbilical vein endothelial cells (HUVECs) were used in the experiments. HMECs were cultured in RPMI 1640 medium supplemented with $10 \% \mathrm{FBS}, 1 \%$ penicillin/streptomycin, $4.76 \mathrm{~g} / \mathrm{l}$ of HEPES, $1 \mathrm{ml} / \mathrm{l}$ of epidermal growth factor (EGF) and $1 \mathrm{mg} / \mathrm{l}$ of hydrocortisone. HUVECs were cultured in medium 199 (M199) supplemented with $0.1 \mathrm{mg} / \mathrm{ml}$ of heparin, 20\% FBS, 1\% penicillin/streptomycin and $2 \mu \mathrm{l} / \mathrm{ml}$ endothelial cell growth supplement (ECGS). Rat bone-marrow mesenchymal stem cells (MSCs) were cultured in Dulbecco's modified Eagle's medium (DMEM) supplemented with $10 \%$ FBS and $1 \%$ penicillin/streptomycin. The cells lines were maintained at $37^{\circ} \mathrm{C}$ in a humidified $5 \% \mathrm{CO}_{2}$ atmosphere.

\subsection{MTS toxicity assay}

HMECs $\left(2 \times 10^{5}\right.$ cells $\left./ \mathrm{ml}\right)$ were grown until $70-90 \%$ confluence and incubated with different concentrations of synthetic and recombinant LL37 for $24 \mathrm{~h}$ in 96 -well plates. Toxicity was confirmed using 10\% DMSO. Cells were washed twice with PBS and their viability was assessed using Cell Titer $96{ }^{\circledR}$ Aqueous ONE Solution Reagent (MTS [3-(4,5-dimethylthiazol-2-yl)-5-(3carboxymethoxyphenyl)-2-(4-sulfo-phenyl)-2H-tetrazolium] colorimetric assay (Promega, Madison, USA), according to the instructions provided by the manufacturer. Optical density was measured at $492 \mathrm{~nm}$. Results are expressed as percentage of control, which was considered to be $100 \%$.

\subsection{BrdU proliferation assay}

HMECs and HUVECs $\left(6 \times 10^{4}\right.$ cells $\left./ \mathrm{ml}\right)$ were cultured in 24well plates to adhere overnight. The cells were then incubated for $48 \mathrm{~h}$ with synthetic and recombinant LL37, in the presence of 5-bromodeoxyuridine (BrdU) solution at a final concentration of $0.01 \mathrm{mM}$. Proliferation was quantified using In-Situ Detection Kit (BD Biosciences Pharmigen, USA), according to manufacturer's instructions. The results are given as mean \pm SEM and are expressed as percentage of control, which was considered to be $100 \%$.

\subsection{Migration analysis}

Migration assays were performed in transwell BD-matrigel basement membrane matrix inserts (BD-Biosciences, Belgium). The chemotactic capacity of LL37 was evaluated by counting the cells that migrated through the membranes. Transwell inserts containing an $8 \mu \mathrm{m}$ pore-size PET membrane coated with a uniform layer of matrigel basement membrane were used. HUVECs $\left(5 \times 10^{4}\right.$ cells $\left./ \mathrm{ml}\right)$ were seeded on inserts in serum-free medium, and placed on wells containing medium complemented with FBS $2 \%$ and recombinant or synthetic LL37 at a concentration of $5 \mu \mathrm{g} / \mathrm{ml}$. For MSCs $\left(5 \times 10^{4}\right.$ cells $\left./ \mathrm{ml}\right)$, the inserts were placed on wells containing DMEM with BSA $0.1 \%$ and recombinant LL37 at a concentration of $5 \mu \mathrm{g} / \mathrm{ml}$. After incubation for $24 \mathrm{~h}$ membranes were removed from inserts, stained with DAPI-methanol for $5 \mathrm{~min}$ and visualized under a fluorescence microscope. The invading cells 
of each membrane were counted and the results are expressed as percentage of control, which was considered to be $100 \%$.

\subsection{Angiogenesis}

The ability of LL37 to promote the formation of capillary-like structures was examined in Matrigel assay. HMECs and HUVECs $\left(3 \times 10^{4}\right.$ cells/well) were incubated with $5 \mu \mathrm{g} / \mathrm{ml}$ of recombinant and synthetic LL37 for $24 \mathrm{~h}$ on matrigel-coated 96 -well plates. The capillary-like structures in each well were then counted and results are expressed as percentage of control, which was considered to be $100 \%$.

\subsection{Wound healing assay}

C57BL/6 mice (purchased at Charles River, Wilmington, MA) with 8-12 weeks old were used in this study. After general anesthesia, hair on the dorsal side of the animals was shaved and the skin was cleaned with $70 \%$ ethanol. A $5 \mathrm{~mm}$ skin biopsy punch was used to create full thickness cutaneous wounds under aseptic conditions. Two wounds were created on the dorsal surface with one on each side of the midline. LL37 (recombinant or synthetic) and sterile water were applied topically twice a day $(2 \times 10 \mu \mathrm{g}$ in $50 \mu \mathrm{l})$. Wounds were left open and not covered by any type of dressing. To impair healing, mice were treated daily with dexamethasone $(0.25 \mathrm{mg} / \mathrm{kg}$ body weight, intramuscularly). Mice were examined daily for wound-healing progression. After 7 days, the animals were euthanized and wound tissue was collected for histological and immunohistochemistry studies. Skin wound tissue specimens were fixed in $10 \%$ neutral-buffered formalin solution and paraffinembedded. Histological analyzes were performed in $5-\mu \mathrm{m}$ tissue sections.

\subsection{Immunohistochemistry}

Microvesseldensity (MVD) was evaluated in each formalin-fixed paraffin-embedded wounded tissue section by immunohistochemistry. Tissue slides were incubated overnight $8 \mathrm{~h}$ with an anti-CD31 antibody. Briefly, six areas with the highest visible blood vessel density (marked by the vessel marker) per section were selected, and the number of blood vessels was counted per high-power field.

\section{Results}

\subsection{Recombinant P-LL37 neutralizes the activation of macrophages by LPS}

Murine macrophages are known to induce several cytokines, including tumor necrosis factor- $\alpha$ (TNF- $\alpha$ ), upon LPS activation. LPS was added to macrophage cultures to a concentration of $10 \mathrm{ng} / \mathrm{ml}$, either alone or in the presence of $20 \mu \mathrm{g} / \mathrm{ml}$ of recombinant PLL37 or synthetic LL37. Cultures were then incubated for $24 \mathrm{~h}$. The absence of LPS in the recombinant protein was confirmed using the limulus amoebocyte lysate test (data not shown). As expected, the recombinant P-LL37, as well as the synthetic peptide, neutralized the LPS-mediated activation of macrophages (Fig. 1).

\subsection{Toxicity}

In order to evaluate the cytotoxicity of recombinant P-LL37, HMECs were cultured for $24 \mathrm{~h}$ in the presence of the peptide and the cell viability was evaluated by MTS. DMSO $10 \%$ was used as cytotoxic agent, a positive control. As shown in Fig. 2, P-LL37 did not affect viability of HMECs at any of the concentrations used. Actually, with 50 and $500 \mathrm{ng} / \mathrm{ml}$ of P-LL37, a slight increase of viability was observed, indicating that the recombinant peptide P-LL37 might

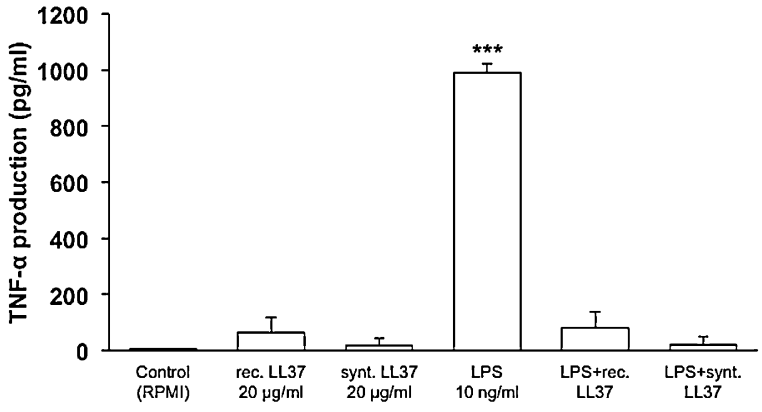

Fig. 1. Recombinant and synthetic LL37 inhibits the TNF- $\alpha$ production by LPSactivated macrophages. ${ }^{* * *} P \leq 0.001$ vs. control.

have promoted proliferation, as previously shown by Koczulla et al. [20].

\subsection{P-LL37 promotes proliferation, migration and tubule-like structures formation by endothelial cells}

Proliferation of HMECs and HUVECs was evaluated using the BrdU incorporation assay. Synthetic LL37 $(5 \mu \mathrm{g} / \mathrm{ml})$ was used as a positive control and $100 \mu \mathrm{M}$ of deoxycholic acid (DCA), an antagonist of FPRL-1, as negative control. DCA attenuates the activation of FPRL-1, by binding to the cell membrane and interfering with the access of the receptor to its agonists [23]. Fig. 3 demonstrates that P-LL37 promoted proliferation with concentrations as low as $50 \mathrm{ng} / \mathrm{ml}$ in HMECs (a) and the effect at $5 \mu \mathrm{g} / \mathrm{ml}$ was very similar to the one obtained using the synthetic LL37. The proliferation of HUVECs (b) was inferior but once again there were no significant differences between synthetic and recombinant peptides.

Next, the chemotactic and angiogenic activities of P-LL37 were evaluated. Fig. 4 illustrates the invasion assays performed with HUVECs (a) and MSCs (b). Again, P-LL37 was able to increase cell invasiveness capacity both in HUVECs and in MSCs. The capacity of LL37 to promote the formation of capillary structures was assessed with HUVECs and HMECs using matrigel as three-dimensional scaffold (Fig. 5). The use of LL37 had a strong effect in angiogenesis. In fact, it almost doubled the number of capillaries formed by HUVECs and HMECs.

\subsection{Wound healing assays}

To further examine the effects and biological activities of synthetic and recombinant LL37, wound healing experiments in dexamethasone-treated mice were performed. The peptides or vehicle were topically applied daily for 7 days in the $5 \mathrm{~mm}$ skin wounds. Dexamethasone was used to impair healing. Fig. 6 illus-

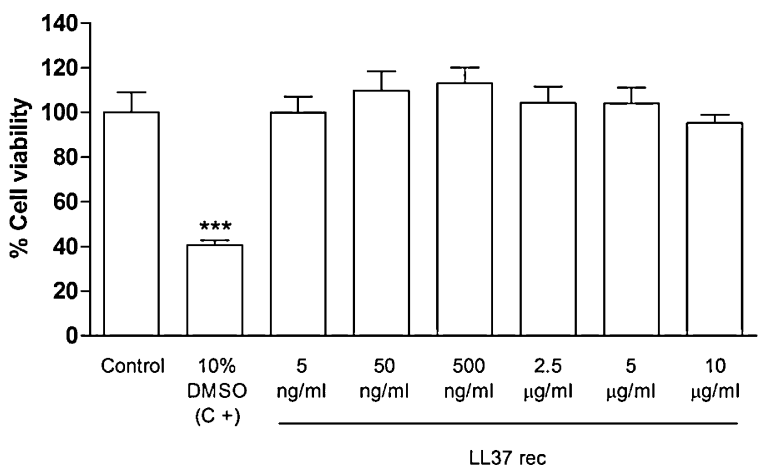

Fig. 2. Cytotoxicity of P-LL37 in confluent HMECs using MTS assay. Three independent experiments were performed in duplicate. ${ }^{* * *} P \leq 0.001$ vs. control. 

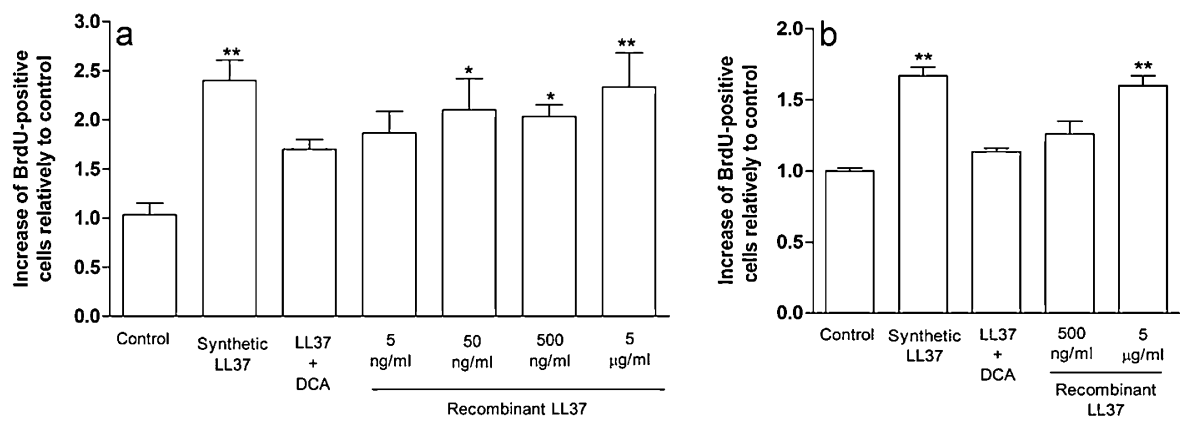

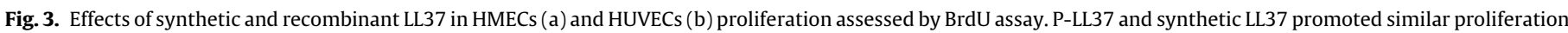
of endothelial cells. Three independent experiments were performed in duplicate. ${ }^{*} P \leq 0.05$ and ${ }^{* *} P \leq 0.01$ vs. control.
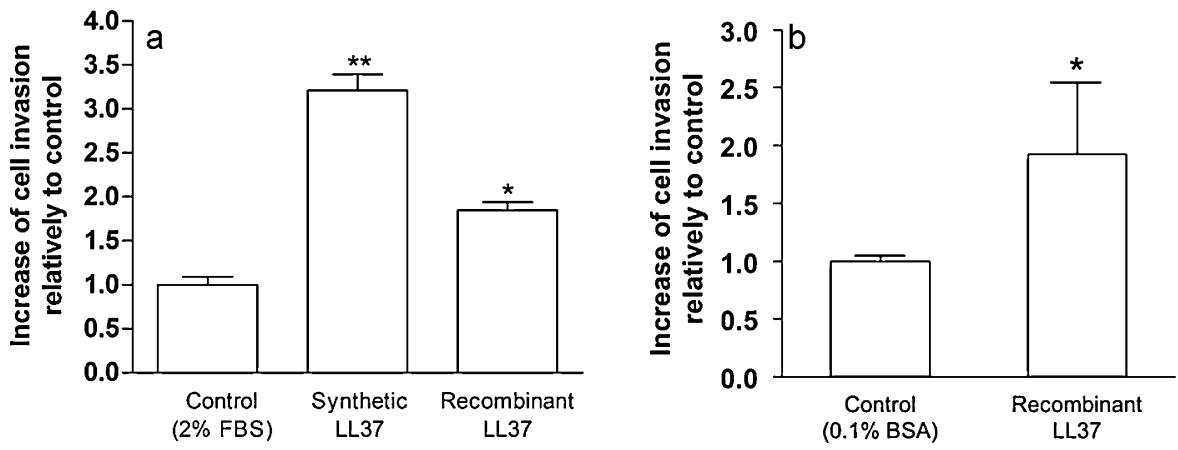

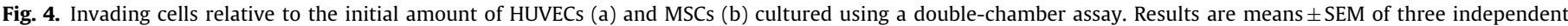
experiments performed in duplicate and expressed relatively to control. ${ }^{*} P \leq 0.05$ and ${ }^{* *} P \leq 0.01$ vs. control.

trates the wounds after daily treatment with recombinant LL37 (two applications of $10 \mu \mathrm{g}$ each) or vehicle, on day seven. The effect of the peptide on wound closure is very strong when comparing to control.

The wound sections stained with hematoxylin and eosin are shown in Fig. 7. No significant differences are found in the granulation tissue with a high number of granulocytes in both cases. However, regarding re-epithelialization, the lesions treated with control or synthetic and recombinant LL37 present large differences. In the control, it is clear that the keranocytes layer is incomplete. On the contrary, in the wounds treated with LL37, the re-epithelialization is almost complete, demonstrating that the healing process is accelerated. More, a high number of blood vessels can be identified in the wounds treated with LL37 (pointed by the arrows), indicating that synthetic or recombinant LL37 strongly promote angiogenesis in vivo. These results were ver-
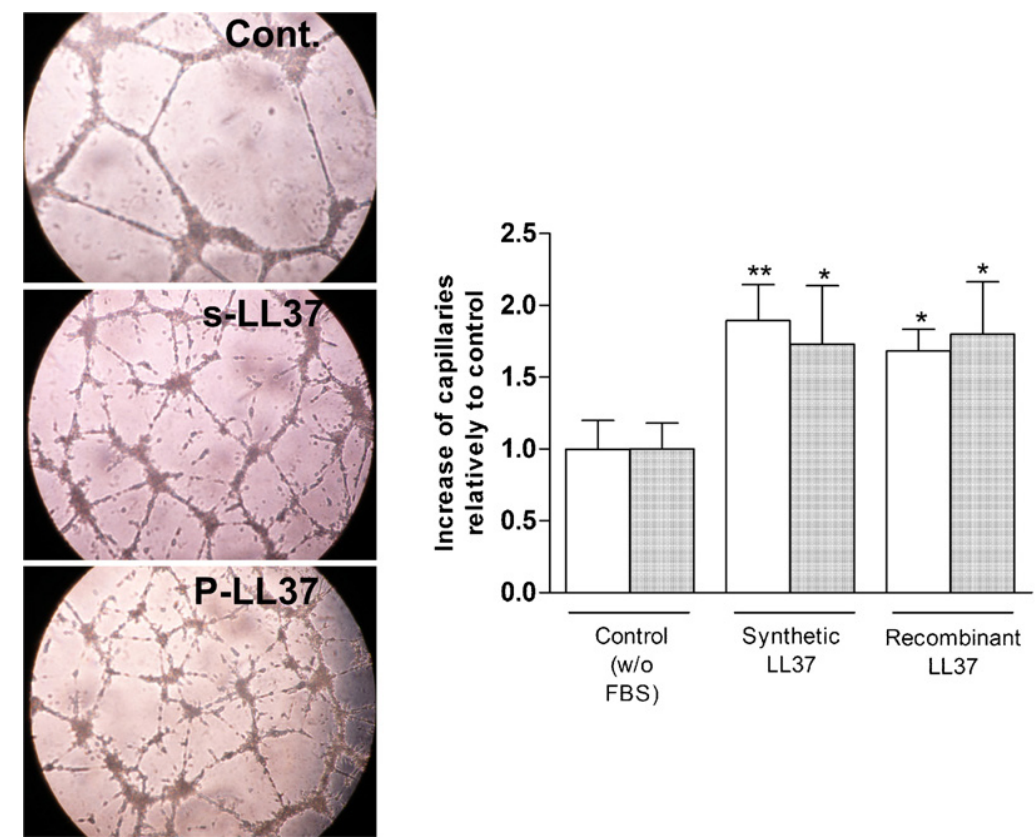

HUVEC

HMEC

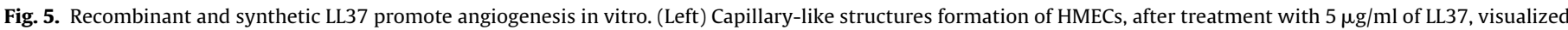

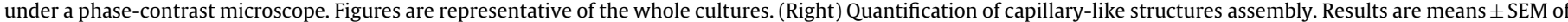
three independent experiments performed in triplicate and expressed relatively to control. ${ }^{*} P \leq 0.05$ and ${ }^{* *} P \leq 0.01$ vs. control. 


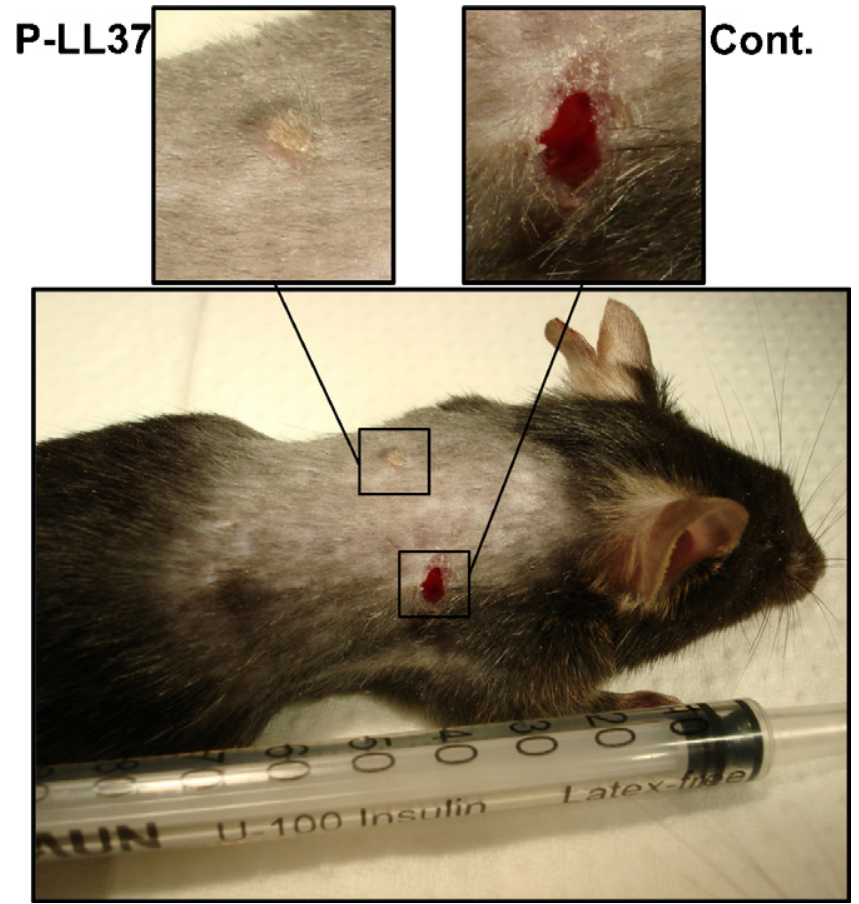

Fig. 6. Macroscopic examination of the wounds at day seven.

ified by immunohistochemistry (Fig. 8). The angiogenic process was confirmed, in our experimental model, by the augmented micro vascular density evaluated by the means of newly formed vessels counted after immunostaining. The wounds treated with either synthetic or recombinant LL37 possess a significantly higher number of new blood vessels. Moreover, the vessels in the tissues treated with the peptide are much larger. Several experiments were performed with both recombinant and synthetic LL37 and similar results were observed. These results clearly demonstrate the ability of LL37 to promote wound healing as a very promising result.

\section{Discussion}

A variety of endotoxins released by the outer membrane of Gram-negative bacteria, namely the lipopolysaccharide (LPS)-protein complex, play an important role in pathogenesis of many exogenous respiratory diseases. The massive release of LPS can lead in extreme cases to endotoxic shock and therefore, death [14]. Many antibiotics release endotoxin by disrupting the cell wall [9,31], and patients cured of bacterial infections can suffer from endotoxic shock. The activation of macrophages is started when LPS binds the LPS-binding protein (LBP). In turn, LBP binds the macrophage surface protein CD14, the primary receptor of LPS, and is 100 -fold more potent than LPS alone [34]. The antimicrobial activity of the peptide LL37 results from the disruption of the bacteria cell wall; however, LL37 can also neutralize LPS activity by forming high affinity complexes [22,35].

The TNF- $\alpha$ production was very low in the presence of either the recombinant or the synthetic peptides, indicating that recombinant P-LL37 has affinity for LPS. The recombinant peptide only differs from the synthetic in one amino acid, a neutral proline resulting from the formic acid hydrolysis [33]. Therefore, the global net charge $(+5)$ remains unaltered. Since electrostatic and hydrophobic interactions are the predominant forces driving the binding between antimicrobial peptides and LPS, these results were expected. However, Rosenfeld et al. [34] described that a strong binding of AMPs-LPS might not be sufficient to neutralize LPSinduced macrophage activation. In fact, those authors showed that the AMP magainin, although binding LPS with high affinity, did not reduce the production of TNF- $\alpha$. Some AMPs, including LL37, can compete with LPS on its binding site within the CD14 receptor, modulating the TLR signaling pathway involving NFKB [25]. Therefore, the inhibition of TNF- $\alpha$ production by LL37 is not only caused by the interaction with LPS. Overall, these results demonstrate that the recombinant peptide P-LL37 is biologically active.

The human antimicrobial peptide LL37 was initially recognized for its antimicrobial properties. In fact, it has a broad spectrum of antimicrobial activity against bacteria, fungi, and viral pathogens, as summarized by Durr et al. [11]. Several studies reported that AMPs loose their antimicrobial activity in elevated salt concentrations and under serum conditions $[2,13,24]$. This inhibition is less pronounced in the case of LL37, probably due to its $\alpha$-helical structure [30]; however, the peptide becomes inactive against certain organisms - susceptible under low salt conditions - in media with $100 \mathrm{mM} \mathrm{NaCl}$ [38]. Furthermore, LL37 had no killing activity against Staphylococcus aureus or Salmonella typhimurium in the presence of tissue-culture medium [5]. Therefore, the relevance of antimicrobial activity in vivo is not clear. However, AMPs are imperative in innate immunity, since animals lacking gene expression of these peptides were more susceptible to infections [28]. Besides its antimicrobial properties, many other activities have been reported for the human peptide LL37. As already stated, LL37 is involved in many aspects of innate immunity, like chemotaxis, angiogenesis or wound healing. Although not completely understood, these activities have been associated to some cells receptors like FPRL-1, P2X and epidermal growth factor receptor (EGFR) [12,19,37]. Among these, LL37 only binds directly to FPRL-1 [42], inducing cellular signaling and $\mathrm{Ca}^{2+}$ flux [20]. So, we have tested the effects of P-LL37 in proliferation, migration and angiogenesis of endothelial cells to ascertain whether the recombinant peptide binds the receptor FPRL-1. The results confirmed that P-LL37 promotes proliferation, migration and tubule-like structures formation by endothelial cells.

The effect of P-LL37 in the migration of HUVECs and MSCs is significant, with an increase of almost $100 \%$ invading cells being observed in both cases. In the experiments with HUVECs, synthetic LL37 promoted a very strong increase in invading capacity, much superior than the one obtained with P-LL37. This result was surprising, since no significant differences were found in the proliferation assays. P-LL37 is obtained by recombinant techniques and the batch used in this experiment could not be as pure as expected, misleading the concentration quantification. A smaller concentration of the recombinant peptide might have been used, which would explain this result. In fact, as illustrated in Fig. 5, the formation of capillary structures was very similar using both peptides. The invasion assay with MSCs was only performed with control and recombinant LL37. Coffelt et al. [8] reported that LL37 was able to chemoattract MSCs through the activation of FPRL-1. Considering all the results obtained, we clearly demonstrate that the recombinant LL37 produced in our laboratory is fully active in vitro. The $\mathrm{N}$-terminus proline, result of the formic acid hydrolysis, does not interfere with the binding of LL37-LPS and to the receptor FPRL-1.

Glucocorticoids affect almost every phase of wound healing because of their inhibitory effect on gene expression in various cells [40]. Beer et al. [3] showed that dexamethasone inhibits recruitment of various inflammatory cells and gene expression of many key wound healing cytokines and growth factors. During the proliferative and remodeling phases, dexamethasone can inhibit the synthesis of several dermal extracellular matrix (ECM) proteins, and delay re-epithelialization and fibroplasia. The healing of a skin wound is a complex process requiring the collaborative efforts of many different tissues and cell lineages and involves the formation of new extracellular matrix, cell infiltration, and tissue remodeling. Inflammation and angiogenesis are two fundamental physiological conditions implicated in this process. In 


\section{Control}
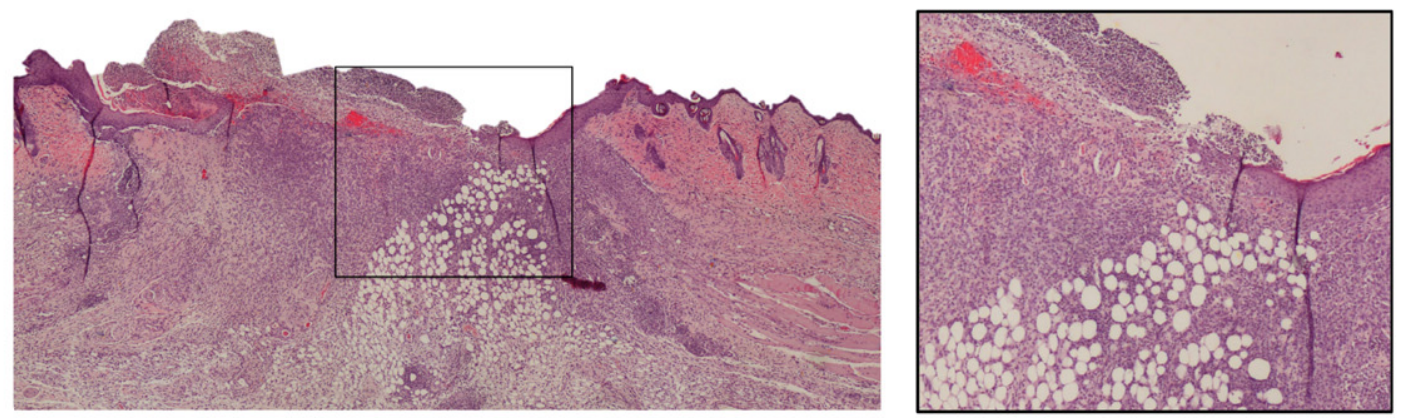

\section{s-LL37}
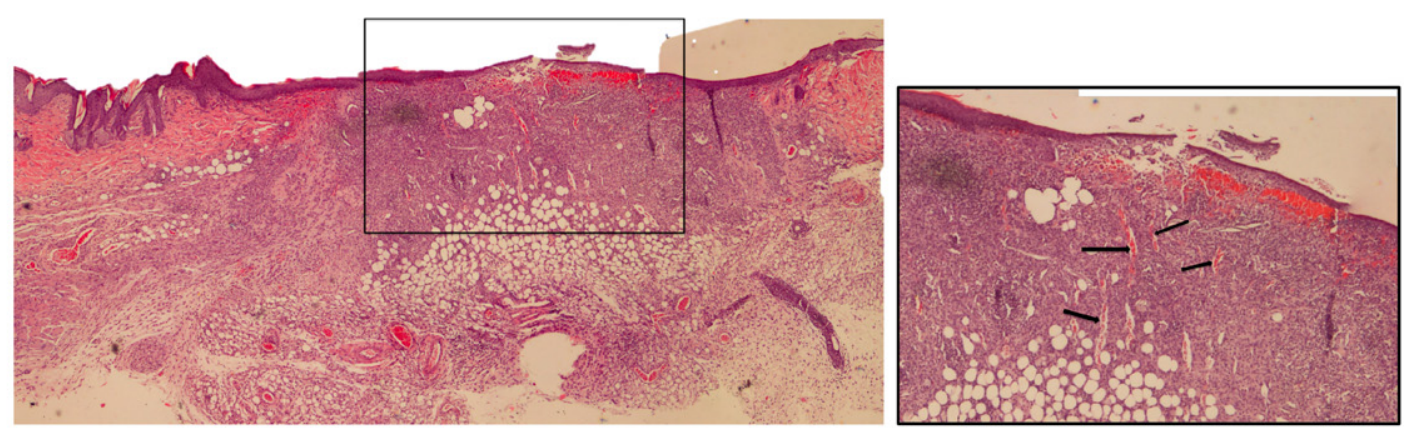

\section{P-LL37}
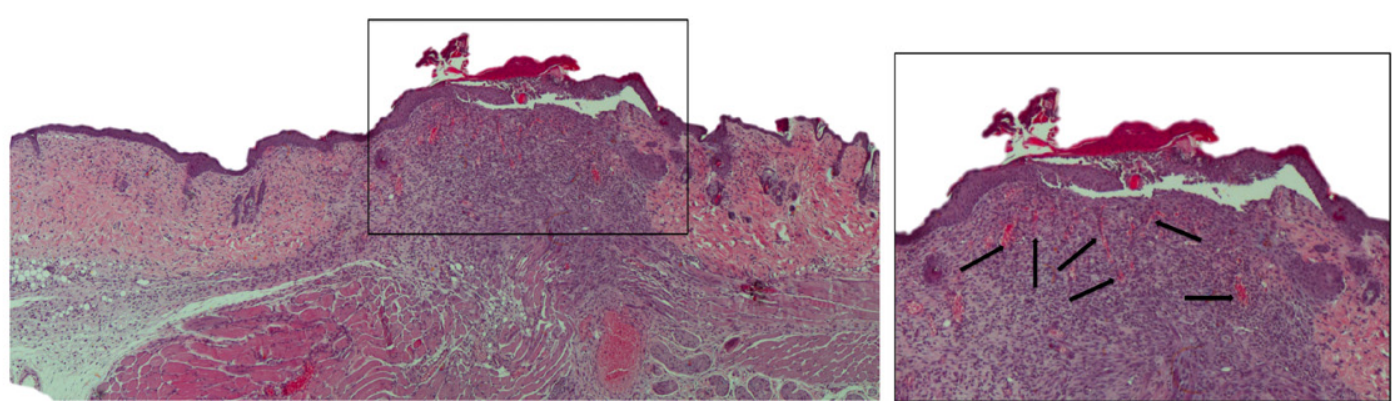

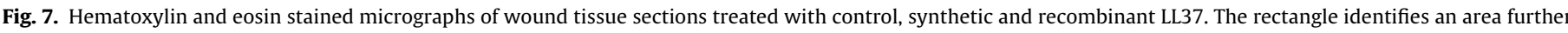

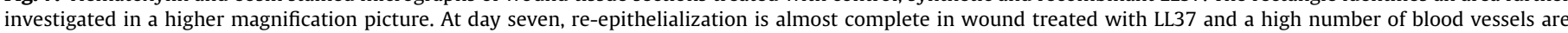
present (pointed by arrows).

fact, the formation of new blood vessels is a prerequisite of tissue repair and wound healing [6]. As already stated and confirmed in this work, LL37 promotes angiogenesis. Moreover, LL37 appears to have a very important role in wound healing. In fact, Heilborn et al. [18] showed that the use of LL37 antibody inhibited reepithelialization in a concentration-dependent manner in an organ cultured full-thickness ex vivo wound model. Moreover, Carretero et al. [7] transferred an adenoviral vector containing LL37 via intradermal injection to excisional wounds in ob/ob mice, improving re-epithelialization and granulation tissue formation. Considering all these results, we decided to study the effects of the topical application of LL37 on wounds. Synthetic and recombinant LL37 strongly accelerated the healing process with a re-epithelialization almost complete after 7 days. Moreover, a significant number of new blood vessels were present in the wounds treated with the peptide.
The importance of LL37 in wound healing has already been presented, but the topical application of LL37 on skin lesions with impaired healing has not been studied so far. In this work, we demonstrate that LL37 can be used topically to support wound healing. The topical application of the peptide allows a better regulation of the process. The applied concentrations can be easily controlled and the administration can be stopped at any moment. Moreover, delivery systems can be used to obtain a regulated administration. The tight regulation of AMPs is very important since elevated amounts may lead to a chronic inflammatory process, as it has been demonstrated for psoriasis and rosacea [29,41]. In order to better understand the role of LL37 in wound healing, further experiments will be performed, namely with diabetic mice. Diabetic mice have impaired healing and it is well known that the healing treatments of diabetic ulcers did not deliver satisfactory results. In this type of lesions, angiogenesis seems to be the most compromised 

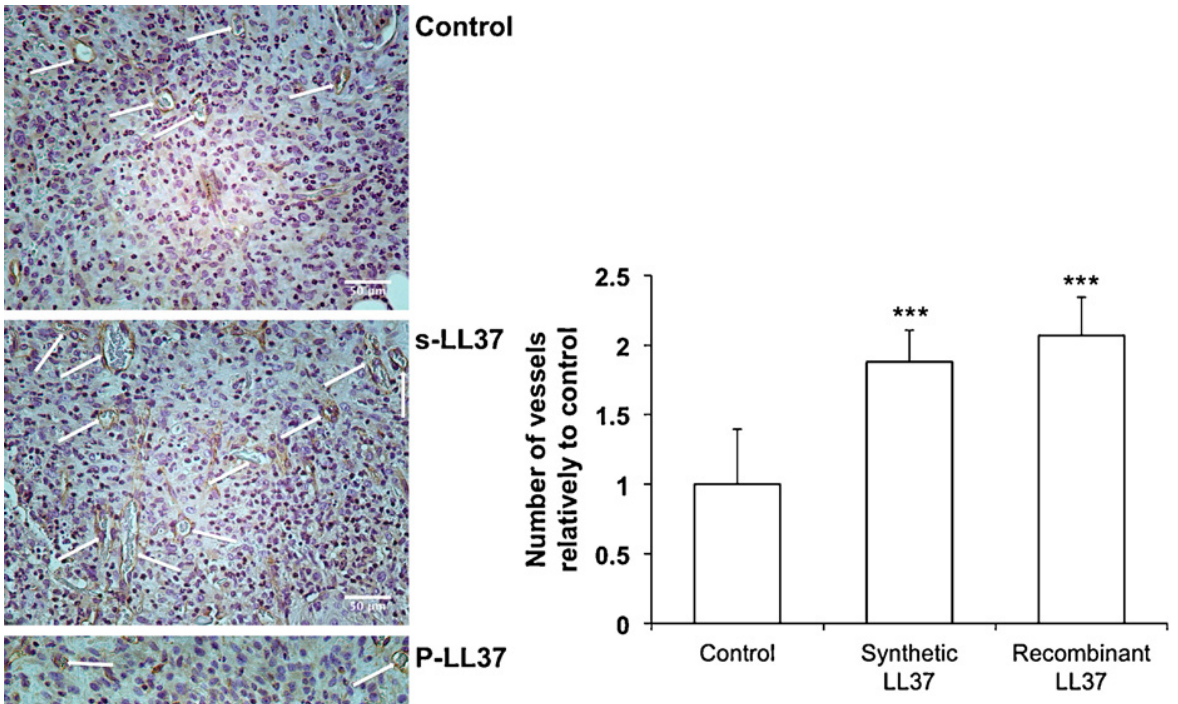

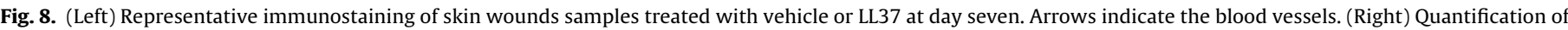
blood vessels. Results are means \pm SEM of three independent experiments and are expressed as percentage of control. ${ }^{* * *} P \leq 0.001$ vs. control.

phase with impairment in VEGF synthesis [4]. Regarding the positive results obtained in this work, we believe that the treatment of diabetic ulcers with LL37 will improve wound healing.

\section{Conflict of interest}

All authors disclose that there is no conflict of interest including any financial, personal or other relationships with other people or organizations. All authors have materially participated in the research and/or article preparation. All authors have approved the final article.

\section{Acknowledgements}

This work was supported by the individual Grant SFRH/BD/ 27404/2006 from Fundaçãopara a Ciência e a Tecnologia (Portugal). We are grateful to Joana Almeida, at the Department of Biochemistry, University of Porto, for the help with the histological analyzes.

\section{References}

[1] Ajesh K, Sreejith K. Peptide antibiotics: an alternative and effective antimicrobial strategy to circumvent fungal infections. Peptides 2009;30:999-1006.

[2] Anderson RC, Yu PL. Factors affecting the antimicrobial activity of ovine-derived cathelicidins against E. coli 0157:H7. Int J Antimicrob Agents 2005;25:205-10.

[3] Beer HD, Fassler R, Werner S. Glucocorticoid-regulated gene expression during cutaneous wound repair. Vitam Horm 2000;59:217-39.

[4] Bitto A, Minutoli L, Altavilla D, Polito F, Fiumara T, Marini H, et al. Simvastatin enhances VEGF production and ameliorates impaired wound healing in experimental diabetes. Pharmacol Res 2008;57:159-69.

[5] Bowdish DME, Davidson DJ, Lau YE, Lee K, Scott MG, Hancock REW. Impact of LL-37 on anti-infective immunity. J Leukoc Biol 2005;77:451-9.

[6] Carmeliet P. Mechanisms of angiogenesis and arteriogenesis. Nat Med 2000;6:389-95

[7] Carretero M, Escamez MJ, Garcia M, Duarte B, Holguin A, Retamosa L, et al. In vitro and in vivo wound healing-promoting activities of human cathelicidin LL-37. J Invest Dermatol 2008;128:223-36.

[8] Coffelt SB, Marini FC, Watson K, Zwezdaryk KJ, Dembinski JL, LaMarca HL, et al. The pro-inflammatory peptide LL-37 promotes ovarian tumor progression through recruitment of multipotent mesenchymal stromal cells. Proc Natl Acad Sci USA 2009;106:3806-11.
[9] Cohen J, McConnell JS. Antibiotic-induced endotoxin release. Lancet 1985;2:1069-70.

[10] Diegelmann RF, Evans MC. Wound healing: an overview of acute, fibrotic and delayed healing. Front Biosci 2004;9:283-9.

[11] Durr UH, Sudheendra US, Ramamoorthy A. LL-37, the only human member of the cathelicidin family of antimicrobial peptides. Biochim Biophys Acta 2006;1758:1408-25.

[12] Elssner A, Duncan M, Gavrilin M, Wewers MD. A novel P2X7 receptor activator the human cathelicidin-derived peptide LL37, induces IL- 1 beta processing and release. J Immunol 2004;172:4987-94.

[13] Goldman MJ, Anderson GM, Stolzenberg ED, Kari UP, Zasloff M, Wilson JM. Human beta-defensin-1 is a salt-sensitive antibiotic in lung that is inactivated in cystic fibrosis. Cell 1997;88:553-60.

[14] Golec M. Cathelicidin LL-37: LPS-neutralizing, pleiotropic peptide. Ann Agric Environ Med 2007;14:1-4.

[15] Gough M, Hancock RE, Kelly NM. Antiendotoxin activity of cationic peptide antimicrobial agents. Infect Immun 1996;64:4922-7.

[16] Hancock RE. Cationic peptides: effectors in innate immunity and novel antimicrobials. Lancet Infect Dis 2001;1:156-64.

[17] Hancock RE, Diamond G. The role of cationic antimicrobial peptides in innate host defences. Trends Microbiol 2000:8:402-10.

[18] Heilborn JD, Nilsson MF, Kratz G, Weber G, Sorensen O, Borregaard N, et al. The cathelicidin anti-microbial peptide LL-37 is involved in re-epithelialization of human skin wounds and is lacking in chronic ulcer epithelium. J Invest Dermatol 2003;120:379-89.

[19] Kajiya M, Shiba H, Komatsuzawa H, Ouhara K, Fujita T, Takeda K, et al. The antimicrobial peptide LL37 induces the migration of human pulp cells: a possible adjunct for regenerative endodontics. J Endod 2010;36: 1009-13.

[20] Koczulla R, von Degenfeld G, Kupatt C, Krotz F, Zahler S, Gloe T, et al. An angiogenic role for the human peptide antibiotic LL-37/hCAP-18. J Clin Invest 2003;111:1665-72.

[21] Kurosaka K, Chen Q, Yarovinsky F, Oppenheim JJ, Yang D. Mouse cathelinrelated antimicrobial peptide chemoattracts leukocytes using formyl peptide receptor-like 1 /mouse formyl peptide receptor-like 2 as the receptor and acts as an immune adjuvant. J Immunol 2005;174:6257-65.

[22] Larrick JW, Hirata M, Balint RF, Lee J, Zhong J, Wright SC. Human CAP18: a novel antimicrobial lipopolysaccharide-binding protein. Infect Immun 1995;63:1291-7.

[23] Le YY, Yang YM, Cui YH, Yazawa H, Gong WH, Qiu CP, et al. Receptors for chemotactic formyl peptides as pharmacological targets. Int Immunopharmacol 2002;2:1-13.

[24] Lee IH, Cho Y, Lehrer RI. Effects of $\mathrm{pH}$ and salinity on the antimicrobial properties of clavanins. Infect Immun 1997;65:2898-903.

[25] Mookherjee N, Brown KL, Bowdish DM, Doria S, Falsafi R, Hokamp K, et al. Modulation of the TLR-mediated inflammatory response by the endogenous human host defense peptide LL-37. J Immunol 2006;176:2455-64. 
[26] Mosmann T. Rapid colorimetric assay for cellular growth and survival: application to proliferation and cytotoxicity assays. J Immunol Methods 1983;65:55-63.

[27] Niyonsaba F, Iwabuchi K, Someya A, Hirata M, Matsuda H, Ogawa H, et al. A cathelicidin family of human antibacterial peptide LL-37 induces mast cell chemotaxis. Immunology 2002;106:20-6.

[28] Nizet V, Ohtake T, Lauth X, Trowbridge J, Rudisill J, Dorschner RA, et al. Innate antimicrobial peptide protects the skin from invasive bacterial infection. Nature 2001;414:454-7.

[29] Ong PY, Ohtake T, Brandt C, Strickland I, Boguniewicz M, Ganz T, et al. Endogenous antimicrobial peptides and skin infections in atopic dermatitis. $\mathrm{N}$ Engl J Med 2002;347:1151-60.

[30] Park IY, Cho JH, Kim KS, Kim YB, Kim MS, Kim SC. Helix stability confers salt resistance upon helical antimicrobial peptides. J Biol Chem 2004;279:13896-901.

[31] Prins JM, Kuijper EJ, Mevissen ML, Speelman P, van Deventer SJ. Release of tumor necrosis factor alpha and interleukin 6 during antibiotic killing of Escherichia coli in whole blood: influence of antibiotic class, antibiotic concentration, and presence of septic serum. Infect Immun 1995;63:2236-42.

[32] Ramanathan B, Davis EG, Ross CR, Blecha F. Cathelicidins: microbicidal activity, mechanisms of action, and roles in innate immunity. Microbes Infect 2002;4:361-72.

[33] Ramos R, Domingues L, Gama M. Escherichia coli expression and purification of LL37 fused to a family III carbohydrate-binding module from Clostridium thermocellum. Protein Expr Purif 2010; 71: 1-7.

[34] Rosenfeld Y, Papo N, Shai Y. Endotoxin (lipopolysaccharide) neutralization by innate immunity host-defense peptides. Peptide properties and plausible modes of action. J Biol Chem 2006;281:1636-43.
[35] Scott MG, Davidson DJ, Gold MR, Bowdish D, Hancock RE. The human antimicrobial peptide LL-37 is a multifunctional modulator of innate immune responses. J Immunol 2002;169:3883-91.

[36] Sorensen OE, Follin P, Johnsen AH, Calafat J, Tjabringa GS, Hiemstra PS, et al. Human cathelicidin, hCAP-18, is processed to the antimicrobial peptide LL-37 by extracellular cleavage with proteinase 3. Blood 2001;97:3951-9.

[37] Tjabringa GS, Aarbiou J, Ninaber DK, Drijfhout JW, Sorensen OE, Borregaard N et al. The antimicrobial peptide LL-37 activates innate immunity at the airway epithelial surface by transactivation of the epidermal growth factor receptor. J Immunol 2003;171:6690-6.

[38] Turner J, Cho Y, Dinh NN, Waring AJ, Lehrer RI. Activities of LL-37, a cathelinassociated antimicrobial peptide of human neutrophils. Antimicrob Agents Chemother 1998;42:2206-14.

[39] Tushinski RJ, Oliver IT, Guilbert LJ, Tynan PW, Warner JR, Stanley ER. Survival of mononuclear phagocytes depends on a lineage-specific growth factor that the differentiated cells selectively destroy. Cell 1982;28:71-81.

[40] Xie Y, Gao K, Hakkinen L, Larjava HS. Mice lacking beta6 integrin in skin show accelerated wound repair in dexamethasone impaired wound healing model. Wound Repair Regen 2009;17:326-39.

[41] Yamasaki K, Di Nardo A, Bardan A, Murakami M, Ohtake T, Coda A, et al Increased serine protease activity and cathelicidin promotes skin inflammation in rosacea. Nat Med 2007;13:975-80.

[42] Yang D, Chen Q, Schmidt AP, Anderson GM, Wang JM, Wooters J, et al. LL-37, the neutrophil granule- and epithelial cell-derived cathelicidin, utilizes formyl peptide receptor-like 1 (FPRL1) as a receptor to chemoattract human peripheral blood neutrophils, monocytes, and T cells. J Exp Med 2000;192:1069-74.

[43] Zhang X, Goncalves R, Mosser DM. The isolation and characterization of murine macrophages. Curr Protoc Immunol 2008;14:1. Chapter 14:Unit. 